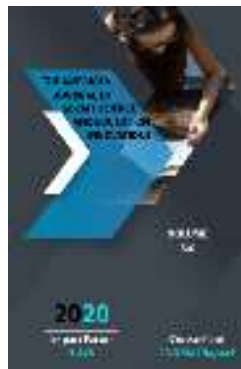

Journal Website: http://usajournalshub.c om/index,php/tajssei

Copyright: Original content from this work may be used under the terms of the creative commons attributes 4.0 licence.

\section{Improving Student's Learning Through Oral Feedback In An English As A Foreign Language Classroom}

\author{
Yulduz Mamutova \\ English Teacher At The Department Of English Language And Literature, Karakalpak State \\ University Named After Berdakh, Uzbekistan
}

Biybiayim Maulenbergenova

Student Of The Department Of English Language And Literature, Karakalpak State University Named After Berdakh, Uzbekistan

\title{
ABSTRACT
}

The present work is devoted to the analysis of characteristics of a good feedback and different ways of an effective usage of oral feedback in an EFL classroom. The paper elucidates the advantages and disadvantages of oral feedback, and the value of teachers' feedback in developing students' learning.

\section{KEYWORDS}

Feedback, students, teacher, EFL, comments, oral feedback, strategies.

\section{INTRODUCTION}

Feedback is an important part of education which has either a positive or negative influence on the learning process. As Ur defines, feedback is information that is given to the learner about his or her performance of the learning task, usually with the objective of improving their performance [11; p.242].

Students' making mistakes in language learning is natural, and giving feedback by a teacher is crucial part of the process of language education. On this occasion, the 
feedback should be done well to be effective and contribute to students' language learning development.

An effective feedback allows students to understand what to do next and how to improve their performance. It focuses on students feeling free to take risks and make mistakes as they progress. Teachers' feedback acknowledges that every student, regardless of achievement, has unused opportunities. The purpose of feedback is to identify and help continuously direct a student's understanding or performance towards a learning goal.

In EFL lessons, it is essential to respond to the students' speech in order to show the teacher's attention to the students. Oral feedback serves as a primary tool in classroom activities. Providing verbal feedback during the activities create an interaction between students and a teacher, which will help the students do their best toward the target language.

\section{CHARACTERISTICS OF A GOOD FEEDBACK}

A feedback has a negative rather than positive impact unless it meets specific requirements. Teachers need to be able to integrate feedback processes with their pedagogical content knowledge in order to better attend to student learning needs and to provide useful feedback. [5] The followings are a few characteristics of an effective feedback:

- "To be effective, feedback needs to be clear, purposeful, meaningful, and compatible with students' prior knowledge and to provide logical connections" [4; p.104].

- Students are given some specific instructions. If a teacher gives a cursory feedback with nonspecific instructions, the student easily forgets the feedback or fails to understand how to move forward.
Example: An 8th grade student of a Karakalpak secondary school studying English as a foreign language gives a poster presentation about environment. After the completion of her performance, the teacher comments: "You worked hard and you deserve to succeed. However, I noticed you made mistakes in your pronunciation. If you work on it you will definitely improve".

The feedback seems to have negligible amount of detailed instruction. First, nothing is said about what exactly was sufficient (ability to engage audience, body language, accurate grammar, or the presence of a good introduction and etc.). Secondly, it would be better to point pronunciation mistakes specifically. For example, "You often made mistakes with pronouncing words ending with ng. Remember that when the ng comes at the end of a word, you do not pronounce the g, but pronounce it like [n]. You should have said paluti:n not palu:ting".

- A good feedback serves to encourage the student.

When oral feedback consists of positive comments such as "good", "ok", "yes", and "well done", it provides support to the student and fortifies motivation for learning sustainability [2]. Stenger believes that feedback can negatively influence learning if presented in a negative or only corrective way. He empathizes the fact that students who experience learning English as positive are less likely to suffer from foreign language anxiety [10].

Most of the students of secondary schools are not fully ready to receive negative feedback, so if the teacher wants to help the student improve, or mention about what has been wrong and what the teacher has been dissatisfied with, it should be delivered in a positive way. 
- A model or example is provided.

The feedback is effective when the learners are given examples or hints of how to carry out an assignment satisfactorily, or provide more words with a particular sound to show how this sound is pronounced, for example.

- Oral feedback is efficient when the whole class is involved

According to Kwong, even though feedback can be provided individually, it is more effective if the whole class is involved so that students can learn from each other's mistakes [3]. It can help students compare their own performance with the others' and to identify their own strengths and weaknesses.

However, if the teacher does not want the student to feel embarrassed when he or she needs to give some constructive criticism on a particular assignment, it is better to provide it individually.

- There are no comparisons with other students' work, performance or presentation

When giving feedback to a particular student in front of the whole class, it is better not to compare his or her assignment with others' by pointing out weaknesses of the former, as it lowers the student's self-esteem.

\section{ORAL FEEDBACK}

The most common type of feedback is an oral feedback, which can be used in improving students' foreign language acquisition.

Oral feedback is a part of verbal interaction between students and teachers, or students and students [1]. Teachers' oral feedback is a primary method to respond the learners' answers or assignments, to assist students' language learning development.

As Sinclair and Coulthard mention, a typical exchange in the classroom consists of an initiation by the teacher, followed by a response from the pupil, followed by feedback, to the pupil's response from the teacher ..." [9].

For example,

Teacher: Can we say the beautifuliest?

Student: No, the most beautiful.

Teacher: Yes, you are right, the most beautiful.

Oral feedback is classified into several types based on its function. The most common ones are:

- Corrective feedback, which is focused on the issue and provided by a teacher or peer to correct the receiver's mistakes and errors, and to offer help;

- Evaluative feedback, which is a summary of how well a student has performed on a particular assignment. It can be delivered in the form of such comments as "Well done!", "Your pronunciation is improving" etc.

- Descriptive feedback, for example, "You seem to have difficulty with correct word choice", etc.

There are various types of feedback, and it is important to select an appropriate one based on students' needs and the instructional activities [7].

Examining English teachers' opinions of a Karakalpak secondary school regarding oral feedback and analyzing the collected data, it was found out that the following verbal feedback types are mostly employed in EFL classrooms:

1.Praise or encouragement.

Teacher: What else can you see in the picture? 
Student: A man has bumped his head.

Teacher: Yes. Well Done! Good choice of word.

In this example, the teacher praises the student's answer by saying "Yes. Well done! Good choice of word" to indicate that the student's response is acceptable.

2. Corrective feedback. The most common error correction techniques among secondary school teachers are: a) elicitation, b) recast and c) repetition:

a) Student: Every Friday Salamat and his brother goes to downtown.

Teacher: Every Friday Salamat and his brother...

Here the teacher starts the sentence and stops where there was an error.

b) Student: He picked the ball.

Teacher: He picked up the ball. Okay.

The teacher directly corrects the error herself.

c) Student: Yesterday Sara has gone to the cinema.

Teacher: Yesterday Sara has gone to the cinema?

The teacher repeats the student's sentence and emphasizes the error in order to draw his or her attention to it.

It is clear that elicitation and repetition techniques let the students have some time to think about their answers and promote selfcorrection, while recast is used when the teacher wants to correct an error implicitly.

\section{Advantages And Disadvantages}

Verbal feedback is effective because a teacher can explain exactly what he or she means to students, and an immediate response by students is obtained.
Raimes states that oral feedback can be efficient way of feedback provision because of interaction between learner and teacher; this can also lead to comprehensive understanding that can contribute to the learners' achievement [8].

Oral feedback is comfortable in correcting students' spoken language, and learners can improve it for next time. Furthermore, It offers more opportunity for dialogue between a teacher and students, ensuring that they understand the feedback, enabling them to respond to it and to action the feedback straight away.

Although, it may be true to say that feedback could be more effective if oral feedback is combined with written feedback for greater performance in writing. It takes too much time to inform verbally about all grammar, spelling, lexical or other mistakes for each student, so the teacher should provide clear and meaningful comments at the end of the work, so that students can read them individually. Hyland states that the time spent dealing with errors in class is better spent on additional writing practice [6].

\section{STRATEGIES}

We have several strategies for verbal feedback which can be useful for a teacher in enhancing its effectiveness in classrooms.

First, a teacher should smile as he or she speaks in order to encourage students. A smile can help put students at ease. Frowning at the student, even when frustrated with their performance, is never suggested.

Second, feedback should be given in a timely manner. When feedback is provided right after the students' response, their completion of a task or performance, there is a higher probability of their remembering it. 
Next, students should be allowed to respond to feedback to feel involved. Students should know that the teacher is glad to answer any questions that they have.

One more thing to consider is that the teacher should have the students take notes as he or she provides verbal feedback on a test or performance.

Finally, when analyzing the outcomes of tests, or any other written assignments, the teacher should return the papers to students so that they could ask necessary questions.

\section{CONCLUSION}

Developing feedback practices can contribute to students' better learning. An effective feedback given by the teacher informs learners about what they need to do next to make progress.

Oral feedback is an effective tool, which enables students know how well they have performed, and to increase their interests to be more active

It can be concluded from the analysis that the efficiency of feedback depends on different learners and distinct situations.

Data analysis has also shown that corrective, evaluative, descriptive types of verbal feedback are mostly employed by EFL teachers. Almost all types of corrective feedback were used by English teachers of a Karakalpak secondary school, and the most frequently used ones were recast, elicitation and repetition, which were combined with praise at times in order to encourage students.

Based on observations and findings, tips to make feedback effective, advantages and disadvantages of verbal feedback are discussed. The collected data were analyzed to determine which type of oral feedback was most frequently employed by the teachers of a Karakalpak secondary school.

The strategies mentioned in the paper can be employed by both experienced and new EFL teachers, increase their awareness of providing an effective feedback, and help to make the process of providing feedback a positive learning experience for students.

\section{REFERENCES}

1. Brookhart, S. M. (2008). How to give effective feedback to your students.

2. Ellis, R. (2009) 'Editorial', Language Teaching Research, 13(2), p.125-127.

3. Kwong, I. Y. (2009). Motivating students by providing feedback. p1-4.

4. Hattie, J. \& Timperley, H. (2007). The power of feedback. Review of Educational Research, $77(1), \quad$ pp. 81-112: 10.3102/003465430298487 Retrieved from http://rer.sagepub.com/content/77/1/81.fu Il.pdf+html

5. Heitink, M, Van der Kleij, F, Veldkamp, B, Schildkamp, K \& Kippers, W, (2016). 'A systematic review of prerequisites for implementing assessment for learning in classroom practice', Educational Research Review, vol. 17, pp. 50-62.

6. Hyland, K. (2003). Second language writing. Cambridge: Cambridge University Press.

7. Konold, K.E., Miller, S.P. \& Konold, K.B. (2004). Using teacher feedback to enhance student learning. Teaching Exceptional Children, 36 (6), 64-69.

8. Raimes, A. (1983). Techniques in teaching writing. Oxford: Oxford University Press.

9. Sinclair, J.M. and Coulthard, M. (1974) Towards an analysis of discourse: The English used by teachers and pupils. London: Oxford University Press.

10. Stenger M. (2014). 5 Research-Based Tips for Providing Students with Meaningful 
The American Journal of Social Science and Education Innovations (ISSN - 2689-100x)

Published: August 29, 2020 | Pages: 521-526

Doi: https://doi.org/10.37547/tajssei/Volume02Issue08-85

Feedback.

Retrieved

from:.http://www.edutopia.org/blog/tips-

providing-students-meaningful-

feedbackmarianne-stenger [Accessed: 20

October 2015].

11. Ur, P. (1996). A Course in Language

Teaching ; Practice and Theory. New York

: Cambridge University Press.

12. www.teachthought.com 